\title{
Three elements in the construction of spatial identities in Mađir (Banjaluka, Bosnia and Herzegovina) and Ilsvika (Trondheim, Norway) neighbourhoods
}

The modern world is facing rapid urbanisation, increasing urban population, constant growth of cities and the construction of new neighbourhoods. Moreover, new neighbourhoods often lack the elements of identity in the context of the place and the people who live there. Therefore, it is necessary to construct these identities together with the physical and natural structure of place and the cultural identity of the people. The construction of spatial identities has been studied in two case studies of "new" neighbourhoods, Mađir (Banjaluka, BosniaHerzegovina) and Ilsvika (Trondheim, Norway), using a qualitative analysis method. The comparison makes use of a triangle model that includes three elements of identity construction as three points of analysis: a) spatial context, b) participation in processes of planning and construc- tion and c) action in place. The two cultural contexts and two ways of constructing spatial identity in the new neighbourhoods studied show certain similarities and differences. The study points to the universal significance of this phenomenon and indicates that the process could be improved in each case by applying positive experiences from the other, with adaptation to the specific context. Considering the importance and interrelation of the three elements involved in construction of spatial identities, they should be harmonised in all stages of development.

Keywords: elements of construction, spatial identities, new neighbourhoods, Mađir (Bosnia-Herzegovina), Ilsvika (Norway) 


\section{Introduction}

The increasing number of people living in cities across the world has promoted the constant growth of cities and the construction of new neighbourhoods. However, in many cases urban development does not reflect a proper relationship towards the context that makes it distinctive, and the new urban form does not contribute to the place identity. Therefore, the construction of identities, as an integral part of place-making, should be considered in parallel with the construction of the physical and natural structure and the cultural identity of the place.

Åshild Lappegard Hauge (2009) states that spatial identity can be seen as one of many manifestations made up of many elements, but here only three elements of identity constructions are highlighted and analysed as three points in the triangle model. We use David Seamon's (2012) approach to the people-place relationship that can be described as a triad of three dimensions of place: 1) geographical ensemble, 2) people-inplace and 3) spirit of place (Figure 1a). In order to adapt this model for specific research, we have transformed this triad into the three elements of identity construction: a) spatial context, b) participation in planning and construction processes and c) action in place (Figure 1b).

As Seamon (2012) states, identity is an integral dimension of a triadic understanding of place experience and place-making. Many writers have defined identity in a similar way, and it is always as an essential element of the construction of the place. Kevin Lynch (1974) defines it in the sense of equality with something else, but with the meaning of individuality or oneness, and Stuart Hall (2000) argues that it forms in relation towards someone else. According to this, one of the key characteristics of a personal identity and a place identity is in the communication between these two identities. By saying that "we are becoming increasingly aware that we are, and always have been, intrinsically spatial beings, active participants in the social construction of our embracing spatialities," Edward W. Soja (1998: 8) argues that identity must be theorised as a socio-spatial phenomenon. William V.J. Neil (2004: 11) states that "construction of identities is always connected with the constitution of a space" and Manuel de Solà-Morales i Rubió (2003) also considers urban life as a social construct, so Henri Lefebvre (2013) ultimately concludes that urban space is interconnected with social relations and vice versa.

Just like a city or an individual, identity is always in a process of development and is never finalised (Neil, 2004) or complete (Hall, 2000), especially if we take into account the freedom to express individual identities that equally participate in constructing a single unity of a place (Seamon, 2012). Based on great freedoms in personal identities, the unity of a nation's or a cultural space's identity is increasingly being considered somewhat outdated in a modern world, and so the concept of hybridity is being introduced into the discourse (Hall, 2000). Hans Ibelings (2010) states that nothing and no-one entirely coincides with a single identity and Isidora Karan (2014) adds that hybrid identity along with different cultural influences can also be seen as a collection of hybrid personal identities that are present in every space. However, the mere presence of a number of personal identities (i.e., the existence of this hybridity alone) is not enough to construct spatial identities because the kind of socio-spatial relationship they have with the place is questionable. For example, through the process of constructing new neighbourhoods, people of varying societal groups and identities become neighbours, but suddenly they do not know how to act and communicate in the public space they have in common (Murphy, 2011).

In the socio-spatial context, place identity can be perceived as the set of meanings that people associate with a particular place and its personal identities, but also with the construction of social identities. Authors who theorised these relations (Norberg-Schulz, 1979; Watson \& Bentley, 2007; Dovey, 2010; Karan, 2014) state that construction of spatial identity deals with the complex relationship between natural, morphological, socio-economic, cultural and other factors. The elements such as physical setting, urban activities and meanings enable orientation in place and identification with it. More precisely, on the scale of neighbourhood, Aksel Tjora et al. (2012) state that housing facilities, public spaces and the community achieved almost always affect the people's social life and their sense of belonging to a neighbourhood. Living in a certain type of neighbourhood could be regarded as an expression of an identity statement but in many cases people cannot identify with their places of residence.

That is why communication is very important in this process of constructing a neighbourhood and its identity, although it is very often hard to achieve. According to Visar Hoxha et al. (2014) social construction of space is perceived as the complex transformation of space through social exchanges and daily use of the material setting into spaces and actions with a particular meaning. Similarly, Seamon (2012) points to the actions, processes and situations by which a place might be improved and transformed through a thoughtful understanding of how places work and what contributes to their virtuous and vicious spirals.

To conclude, although the question of identity is very complex to define because it is never straightforward, unambiguous or comprehensive (Hall, 2000; Castells, 2009; Ibelings, 2010), 


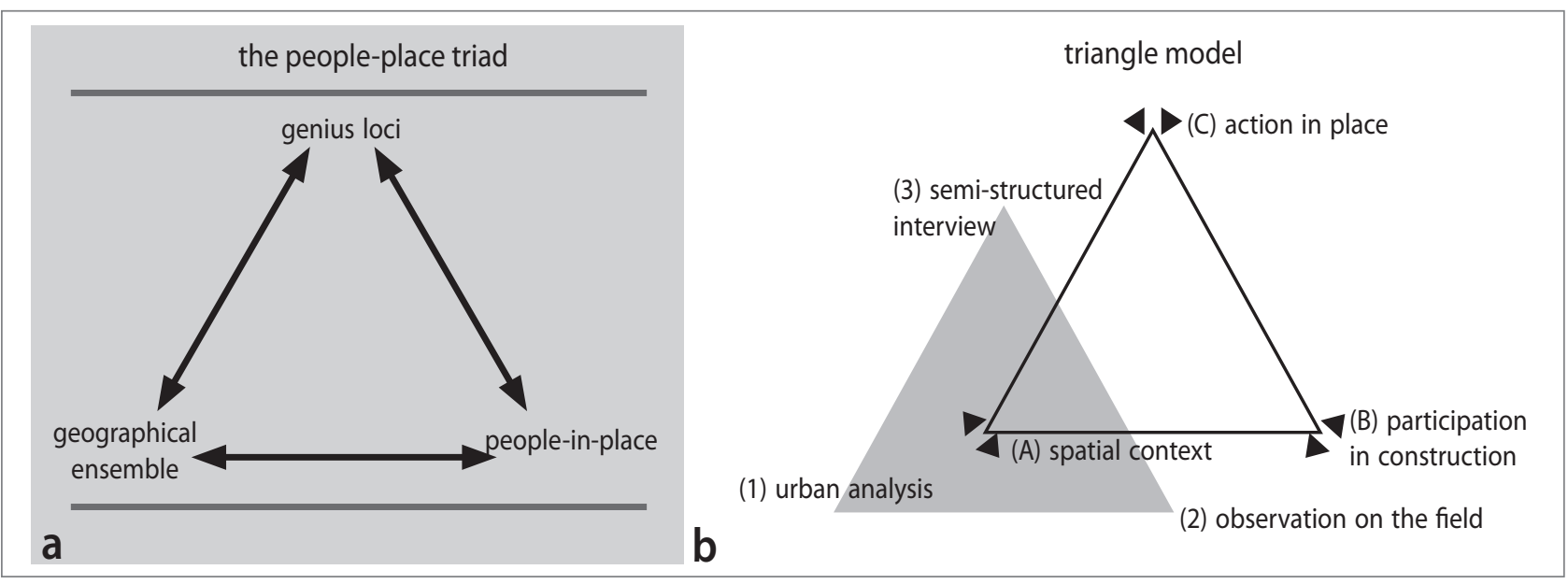

Figure 1: Illustration of analysis used: a) Seamon's the people-place triad (source: Seamon, 2012); b) the triangle model (illustration: Igor Kuvač).

there is no doubt of the relationships between the cultural context, social activities and spatial identity. Identity construction is a continuous process that neither starts nor finishes with the physical construction of a neighbourhood. Therefore, it is important to achieve communication between all participants in the construction of neighbourhood life and identity as soon as possible, at the beginning of the construction process, and to maintain it throughout all stages of development, planning and construction. We attempt to understand the ways identity is constructed based on the relationship towards the neighbourhood and public participation in the community throughout the entire development process.

The construction of identities is studied in two different case studies of "new" neighbourhoods: Madir (Banjaluka, BosniaHerzegovina) and Ilsvika (Trondheim, Norway). The inspiration for this unusual pairing of two "small nations" ${ }^{11}$ is found in Isadora Sekulićs travelogue Letters from Norway (Pisma iz Norveske, 1914) and essay The problem of a small nation (Problem malog naroda, 1932). Although Hall (2000) claims that nations do not have just one cultural identity, there are some general representations of unique "national" identity. The two "nations" of Norway and Bosnia-Herzegovina (formerly part of Yugoslavia) are compared in a discussion of their spatial identities according to their different cultures formed by geography, history, mentality and size. No matter how much the characteristics of one "nation" define it, personal identity therefore depends on who individuals really are, what they own and what they look like, and Sekulić (1932) argues that this ideology is fully applicable to nations as well. ${ }^{[2]}$ Using a triangle model, we address this complex issue by conducting three types of qualitative analysis: 1) urban analysis, 2) field observations and 3) a qualitative analysis of semi-structured interviews. The cross-case analysis compares two different cases of new parts of neighbourhoods as two opposite poles, more than $2,500 \mathrm{~km}$ away from each other. The study points to the universal significance of the phenomenon and suggests that the process can be improved by using others' positive experiences, taking into consideration a certain level of adaptation to the specific context.

\section{Research method}

\subsection{Two cases}

1) Madir is a housing neighbourhood on the northeast edge of Banjaluka (Figure 2a), the second largest city in BosniaHerzegovina with 150,997 residents (Institute of statistics of the Republika Srpska, 2014) and an area of $1,232 \mathrm{~km}^{2}$. It emerged in an informal urban fabric from the need to urgently resolve the "roof over the head" problem, in a spontaneous and unplanned way. It is characterised by the war (1992-1995), suffering and destruction, which was followed by migrations, ${ }^{[3]}$ ongoing transition and other deviant phenomena resulting in devastating consequences for the country (Ministry of finance and treasury of Bosnia and Herzegovina \& Office of the UN resident coordinator in Bosnia and Herzegovina, 2013). Although there is an everyday struggle for the "bare essentials", people continue to remain positive. Their mentality is characterised by warmth and the broad Slavic soul, temperament, spirituality and irrationality that have been shaped for centuries (Cvijić, 1966). Its influences included various conquerors, the reigns of the greatest European empires, four religions and the intersection of a number of cultural influences that give it an identity of rich diversity.

2) Ilsvika is collective housing neighbourhood on the west border of Trondheim (Figure 2b), the third largest city in Norway, with a population of 178,021 residents (Internet 1), situated on the south shore of Trondheim Fjord at the mouth of the river Nidelva. Ilsvika was established within a formal urban 


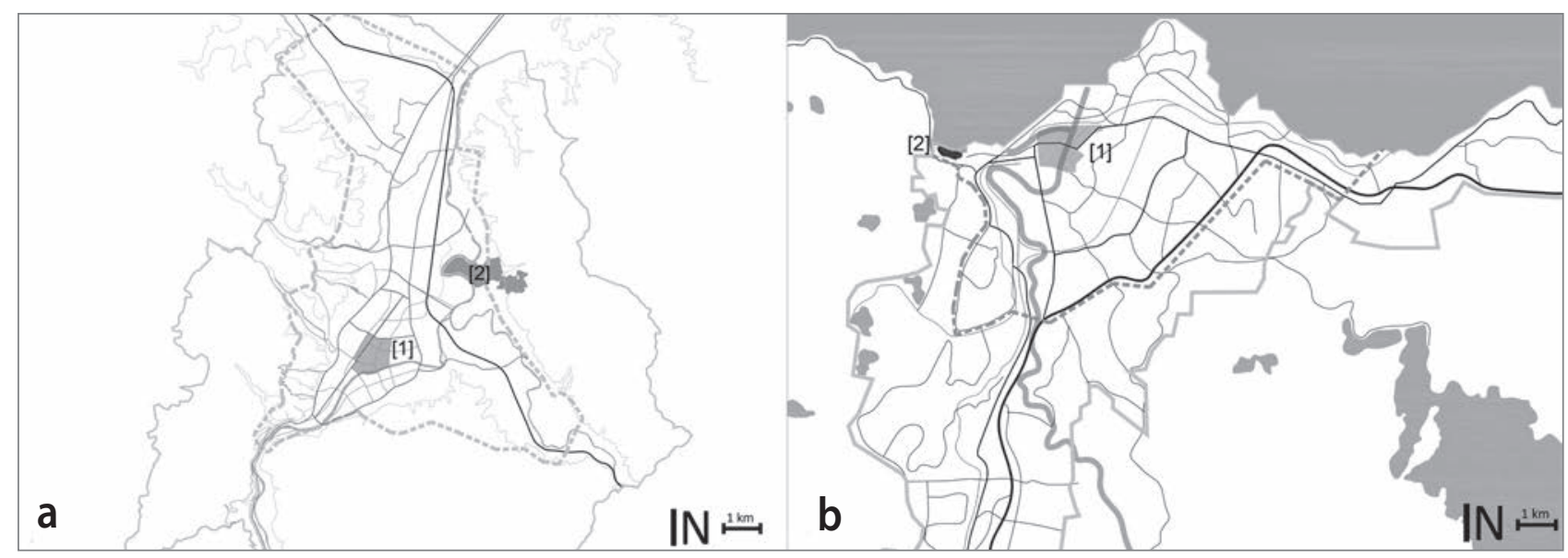

Figure 2: Position of the neighbourhoods in the city: a) Mađir and b) Ilsvika (illustration: Igor Kuvač).

fabric based on market needs and it respects the given standards, laws and regulations. The wider context is determined by economic progress in one of the richest and most developed countries of the world, with high economic stability and social security (OECD, 2014). Norway is characterised by its high level of democracy, human rights and freedoms and also by a high standard of living in harmony with nature and the importance of private space, which is largely reflected in the identity of urban space. On the other hand, its isolated and peripheral position in the far north of Europe, harsh climate with cold winters and lack of sunlight has had an influence on the specific psychology of the people (Hamsun, 1927; Sejranović, 2010). In an inaccessible and sparsely populated country, rich in vast natural beauty, a "small nation" lives characterised by modesty and patience, but also by loneliness, depression and cold (Sekulić, 1914).

\subsection{Triangle model}

A qualitative research method was used to explore the issue of construction of spatial identities, which depends on different factors that cannot be easily quantified (Mason, 2006). According to Manuel Castells (2009), the process always takes place in a context marked by power relationships and includes varied elements from history, geography, religion, sexuality and so forth. According to the qualitative triangle model used (Kvale \& Brinkmann, 2009), this study includes three elements of analysis: 1) urban analysis, 2) field observations and 3) a qualitative analysis of semi-structured interviews. The main emphasis is on the interviews, a method that can illustrate identity as a frame that gives meaning to current behaviour patterns in space and the interviewees' responses to the ways in which their new neighbourhoods were created. This triangle includes three elements of construction of spatial identities: a) spatial context, b) participation in planning and construction processes and c) action in place (Figure 1). The timeframe of twenty years (1995-2015) encompasses the period from the end of the war in Bosnia-Herzegovina and a period of intensive development of both neighbourhoods analysed.

A semi-structured interview was conducted with a small number of participants. A nonpurposive sampling technique was used because of its power to gain access to the subjects and describe everyday life. It is recognised that the explorative potential of personal and subjective perspectives in an interview that enables qualitative descriptions provides a respective understanding and leads to well-controlled findings. Therefore, qualitative narrative interviews do not test hypotheses, but rather reflect common sense and interpretations in which different readers can find different meanings depending on their subjective impressions, and their findings are not generalisable.

Seven in-depth interviews were conducted with residents of the Madir neighbourhood in Banjaluka from 22 to 30 December 2014. The interviewees were four men and three women varying in age, occupation and social status and included both old and new residents in addition to representatives of the NGO and local community sectors. Interviews in Trondheim with the residents of Ilsvika were conducted from 9 to 16 March 2015. Five in-depth interviews were conducted with randomly chosen interviewees, all men varying in age, occupation and social status.

Interviews followed a research protocol that leads to follow-up questions and a critical common-sense understanding (Kvale \& Brinkmann, 2009). They were formed of three sets of questions around which the conversation developed, with a duration of approximately 45 minutes. The research instrument included derived constructs that link the three elements of spatial identity construction mentioned: a) urban structure and relation to the old part of the neighbourhood and the city, b) interests in the planning process and influences on the design solutions 
Table 1: Grouping of responses

\begin{tabular}{|c|c|c|}
\hline Categories of responses & & Responses by categories \\
\hline \multirow{3}{*}{ Spatial context } & \multirow{3}{*}{ R1 } & Physical and natural structure \\
\hline & & Relation to old part of neighbourhood \\
\hline & & Relation to the city \\
\hline \multirow{3}{*}{ Participation in processes } & \multirow{3}{*}{ R2 } & Interest in local politics and planning processes \\
\hline & & Design of neighbourhood \\
\hline & & Design of housing units \\
\hline \multirow{3}{*}{ Social activities } & \multirow{3}{*}{ R3 } & Using of open public spaces \\
\hline & & Quality of life \\
\hline & & Place attachment \\
\hline
\end{tabular}
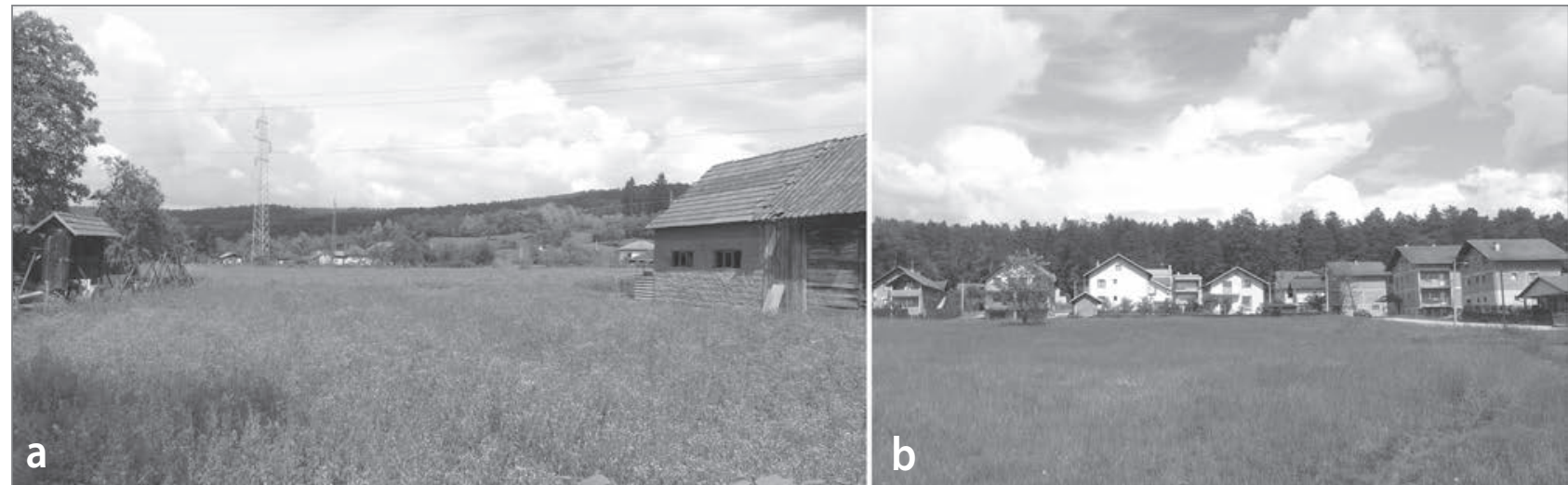

Figure 3: Old a) and new b) parts of the Mađir neighbourhood (photo: Igor Kuvač).

and c) the use of open public spaces, quality of life and feelings about place attachment.

The analysis of the qualitative information obtained is the result of a bricolage technique, which combines elements of analysis into one descriptive hybrid evaluation. The urban analysis and field observations were crossed with the interviewees' responses, which facilitated understanding of the construction process of the new neighbourhoods and their identities. According to the triangle model, responses are grouped into three categories (Table 1).

\section{Elements of identity}

Using the triangle model that informs the study, this section presents the findings of the three approaches mentioned with special reference to the key comments from the interview responses, which enriched the conclusions of the urban-architectural analysis, observations and predictions. The qualitative analysis explores the similarities and differences between each of these elements in both processes of neighbourhood construction observed.

\subsection{Spatial context}

Madir is situated on the right bank of the Vrbas River four kilometres away from the city centre, between protected natural elements: the Madir fields in the west and the Trapisti forest in the northeast. It follows the configuration of the terrain and the spread of the previously parcelled agricultural land determined by the inherited ownership structure, accesses and spatial use. Groups of individual single-family houses that form the old part of the neighbourhood are sparsely arranged in all directions and oriented towards the narrow, curving streets. The traditional vernacular architecture is modest but meets high standards of housing quality with respect to dimensions, function, construction and form $(10 \times 8 \mathrm{~m}, \mathrm{G}+1$, gable roof; Figure 3a).

The new part of the neighbourhood was built through small private investments by refugees and internally displaced persons, who were the main agents of this informal new construction. The new matrix interpolated itself into the prior parcel structure, relying on the field configuration and extending the street grid along contour lines. Parcellation was determined 


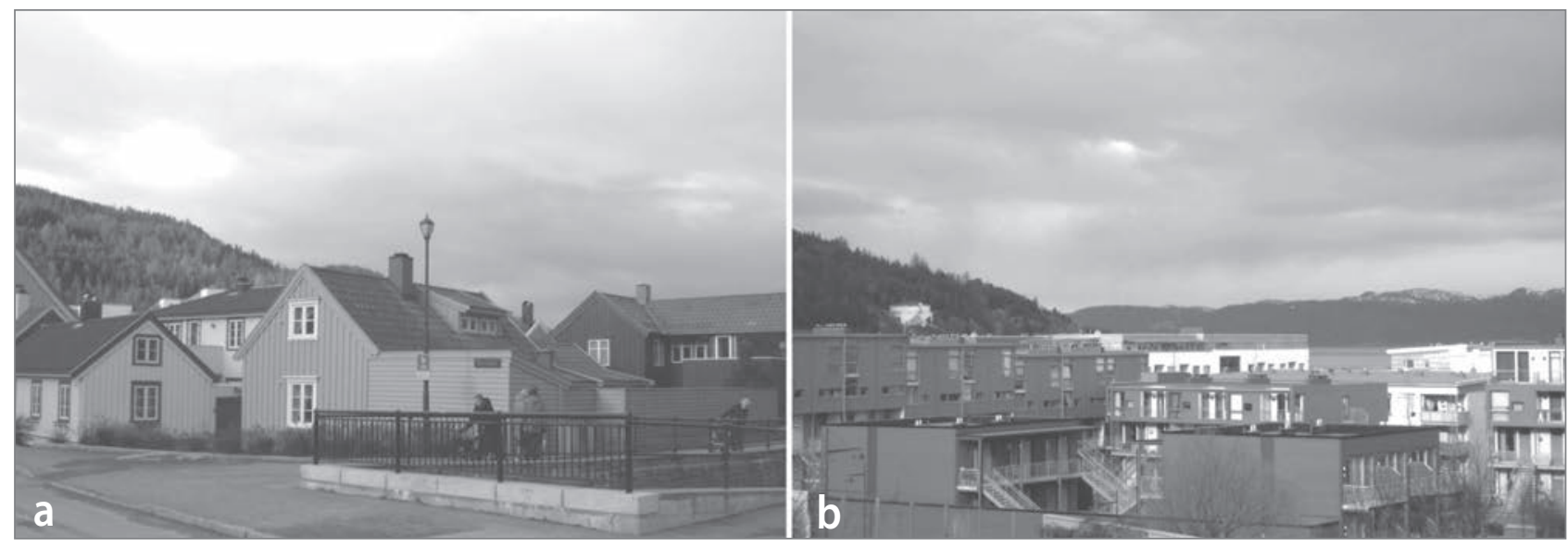

Figure 4: Old a) and new b) parts of the llsvika neighbourhood (photo: Igor Kuvač).

using an adapted traditional housing model that allows the construction of single-family houses and outbuildings, as well as the custom of having a garden. The fragmented physical structure integrates with the natural structure and existing low-density rural structure. It stretches along main transit routes and has a disperse spread, occupying agricultural and forest land around existing urban areas. Self-constructed housing intended for three generations of one family continues to be the only type of housing $(10 \times 8 \mathrm{~m}, \mathrm{G}+1+\mathrm{A}$, a gable roof) and the basic unit of the neighbourhood. Many houses remain unfinished due to economic reasons, one of the key features of the building process. Although they are not considered aesthetically pleasing, they preserve a traditional way of life (Figure $3 \mathrm{~b}$ ) and relationship with the environment, thus contributing to identity values. There is a complete lack of basic infrastructure, transport routes and public facilities.

Ilsvika is located in the west of the city on the periphery (Figure $2 \mathrm{~b}$ ) and it is peaceful because of the quiet natural surroundings of the woods, hills and sea. The majority of the neighbourhood is an old fishing village, Ilsvikora, about two kilometres away from the centre, in a picturesque setting. It consists of small single-family houses $(8 \times 4.8 \mathrm{~m}$, max. two floors) in traditional wooden architecture with sloping gabled roofs, which are arranged in blocks along regulation lines (Figure 4a). Public space within the village is reduced to two little squares that appear at the crossroads of the main transit routes.

The new part of the neighbourhood represents a very strong urban structure on the shore of the fiord, giving it the value of high level of urbanity. This new urbanisation is based on the existing structure of the "village". It goes by the existing urban matrix and respects natural features, the dominant directions of the facilities and the existing open public spaces, but the accomplished relationship is not well enough articulated to achieve integration between the new and the old parts. The urban matrix developed along the central transit route in an east-west direction, parallel to the coast and two perimeter routes: a pedestrian one to the north and a service one to the south. The fjord's coast is the northern border with recreation facilities, whereas the road no. 715 is the southern border with a roundabout as the main access. Its physical structure extends along the east-west axis, consisting of mostly multifamily residential and a few business buildings, but there are also some other facilities such as education, sports and other services. The average building dimensions range from ca. $12 \times$ $36 \mathrm{~m}$ to $14 \times 54 \mathrm{~m}$ and from $\mathrm{G}+2$ up to $\mathrm{G}+5$ floors, so the urban density is very high (Figure $4 \mathrm{~b}$ ). Despite this high level of urbanity, the residents pointed to proximity to nature as the main characteristic of the neighbourhood, including its position in relation to the centre of the city and its excellent transport connections.

Analysis of the spatial context includes the relation between old and new parts of neighbourhoods as an important element of identity and the cultural context related to place.

\subsubsection{Old vs. New}

These relations show connections with tradition and attitudes towards its preservation and protection. The new part of Madir is interpolated between existing dispersed structures, fully compatible with and maintaining a homogenous connection by interpolating itself into and repeating the existing matrix (Figure 3). However, the village does not become a city, so the cultural gap between city and village increases despite of the reduced physical distance and newly-formed dominant cultural layer. Residents define it as a neighbourhood with a character between suburban and rural.

The complexity of the old and new Ilsvika is generated by the integration of the village into the neighbourhood structure by having the new part frame the old one (Figure 4). The new part supplements the old one as an evolutionary process, 


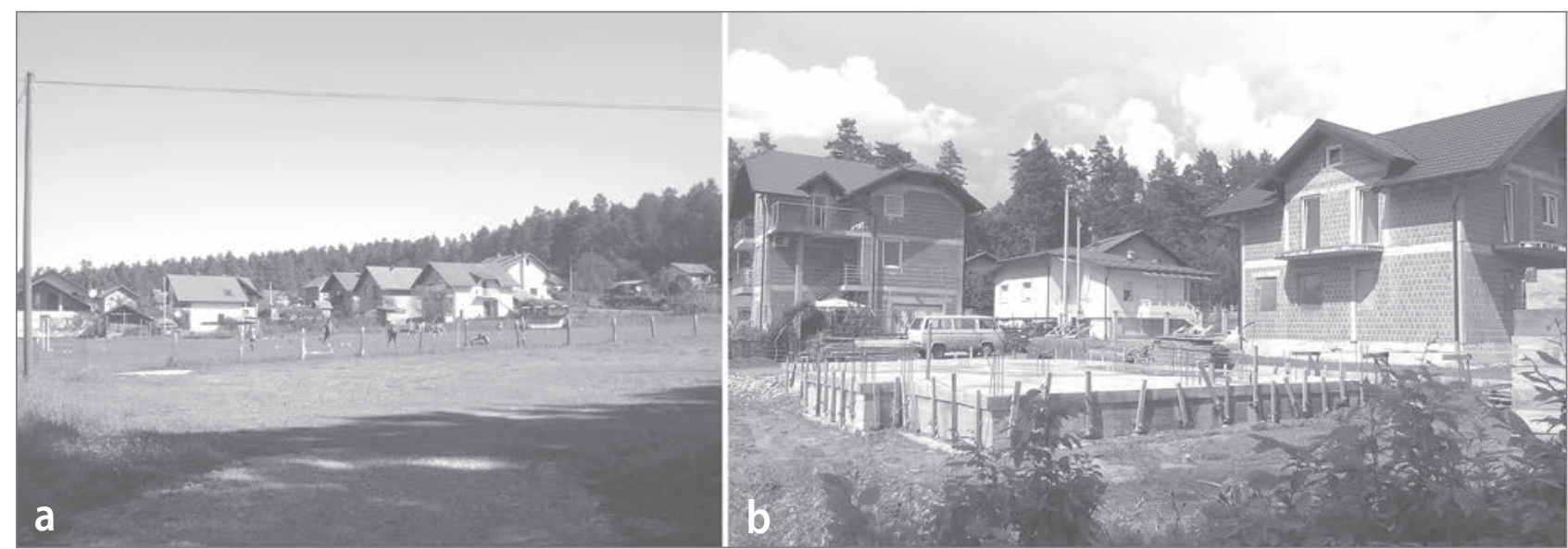

Figure 5: a) Sport activities and b) house construction in Mađir (photo: Igor Kuvač).

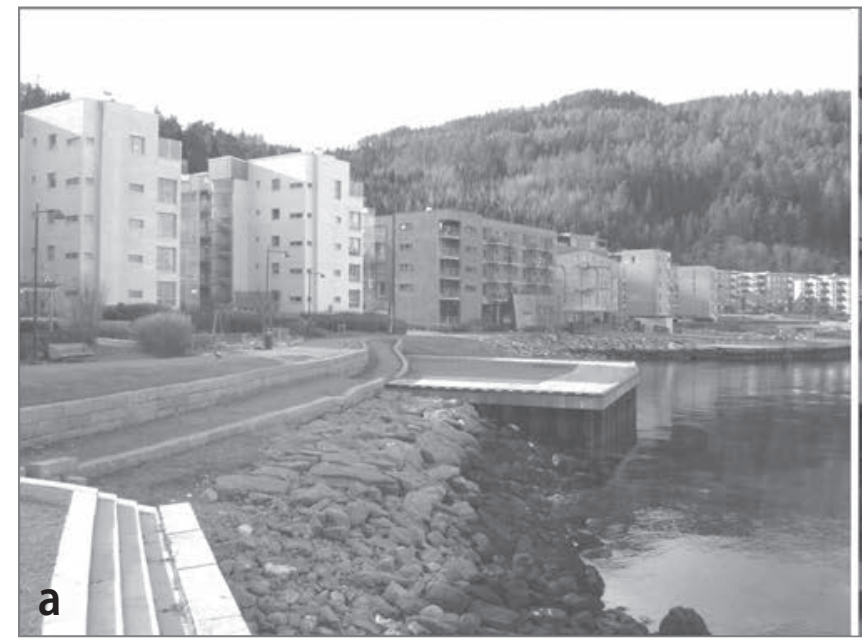

Figure 6: Empty open public spaces in Ilsvika (photo: Igor Kuvač).

which is common and acceptable as a part of the wider context, as residents explained. The specific structure of the village contributes to the continuity of relations to tradition, as well as preservation of inherited values that also facilitate this interaction even in modern surroundings. The new urbanisation uses all the assets of the existing identity that represents a specific place, based on which it forms its advantages. As the city grows, the village becomes closer and more accessible, but on the other hand its residents state that it loses a part of its identity. Although it does not surpass the old image that still exists the new physical appearance of the city is very meaningful. In the conflict of the new and the old, the quantity of the new is the winner versus the quality of the old.

The next section looks at the importance of this relationship between the old and new parts of the neighbourhoods through their urban social activities and residents' attachment to place.

\subsubsection{Place attachment}

The Bosnian people in Madir lead a rich social life, so they have intense communication with one another that makes them feel

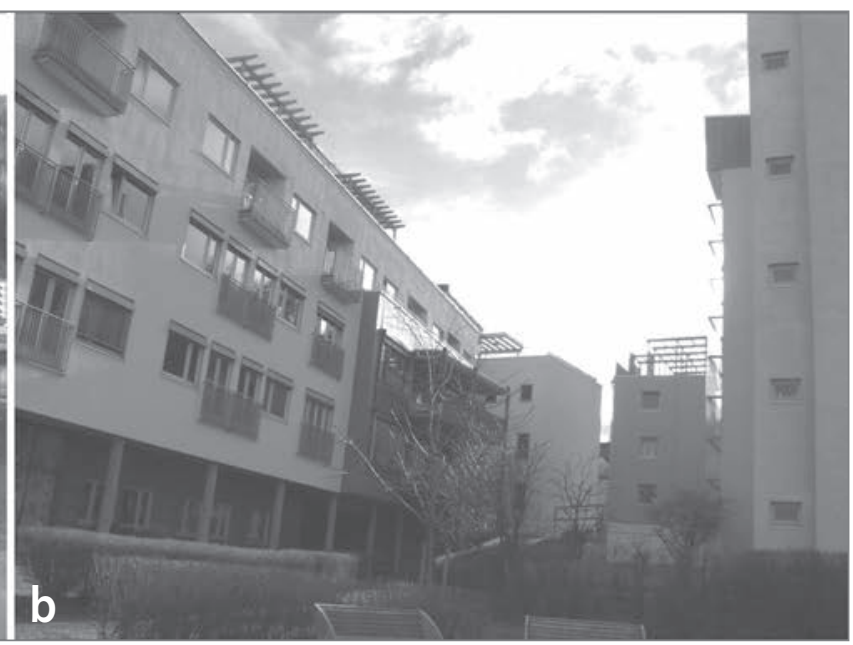

vibrant regardless of the low density and small number of residents in their neighbourhood. In addition, the neighbourhood development is ongoing and dictates everyday activities that depend only on financial and weather conditions. Because the process of construction is never fully complete and many residents maintain the tradition of having a garden, "there is always something to do" (Meili et al. 2012). While residents are working, they make noise with their tools and also chat with their neighbours, family members and passers-by. This makes it seem that the neighbourhood is more vivid than it really is. At the same time, this constant activity and the communication achieved certainly contribute to a stronger place attachment. Indeed, it turns out that the informality of construction as a long-term project has positive effects on identity construction (Figure 5).

Their peripheral position in the far north of Europe, harsh climate with cold and snowy winters, lack of sunlight and the midnight sun phenomenon had an impact on Norwegians' specific mind-set. Christian Norberg-Schulz (1979) says that a Norwegian must like the cold, forest, fog and so on, and Bekim Sejranović (2010) writes of the anguish and dusk in the snowy 
Norwegian mountains that produces the vast Nordic sadness as part of the Norwegian identity. Considering that modern "northern" individuals are liberated from the everyday struggle to survive and to build a house, instead they build their spirit, individuality and diversity through an accumulation of inner energy (Sejranović, 2010). As Neil (2004) points out, a messy interiority produces inner peace and discovery for some people, and also internal reconciliation with an identity that may not be outwardly manifested.

This implies a specific way of life that is complete in itself and does not show the need for interaction in space. This is also reflected in the formal way of constructing a neighbourhood, in which resolving the "roof over the head" issue is not a problem, but just one in a series of tasks, which is normally resolved by buying a fully constructed flat. The living space in collective housing in Ilsvika is reduced to a unit, in which residents "only had the opportunity for some small changes in interior design, not more than that". The attitude towards construction is diametrically opposed to that in Madir, because it is not part of the people's lifestyle or identity, which is constructed in a different way. This is also transposed to the place attachment. Construction and enhancement of identity within this framework is reduced to a minimum. Analysis of the residents' presence in a public space during particular periods of the day confirmed the absence of everyday visible activity despite the high density and number of residents (Figure 6).

\subsection{System of (un)planning}

The main objective of new construction in the Madir neighbourhood was the urgent need to resolve the "roof over the head" problem, which was essential for dozens of displaced newcomer families. Neither the state nor the city were prepared for this process, and so they did not provide plans for new construction. Scarce and outdated planning documentation did not suit conditions for new neighbourhood expansion and so the only possible way for construction to take place was informal. On the other hand, Skotte et al. (2015) point out that authorities acknowledged the situation, and did help the settlers in a way by not intervening, which Meili et al. (2012) calls the "stability of the informal". The new population could not wait for a systemic reaction, so spontaneous informal selfconstruction has been going on without any mediator, following a kind of a bottom-up system. Considering the limited financial resources mentioned above as one of the key features of construction, residents say they "could not pay for expensive technical documents and building permits". However, most of them at least have started the process of obtaining a permit for the construction or post facto legalisation, ${ }^{[4]}$ because they were afraid of making a mistake and wanted to formalise their activities according to the law.
The interviewees state that "the problem should be resolved within a shortest time possible, without complications and with minimum costs". By writing that "we never had enough time to develop our culture in peace", Sekulić (1932) considered this as a continuous part of the Yugoslav identity almost a century ago. In such conditions, the informal self-builder is focused only on himself and his own life. He does not have the need to communicate with institutions he does not trust (Transparency International Bosnia and Herzegovina, 2014), and thus does not build any relationship with public space and does not show any kind of interest in future developments. This mind-set has become obvious, because the ongoing problem of habitat is placed as a priority without considering their future lifestyle needs (Aranya \& Ulset, 2015).

The self-directed process starts with the choice of the location and buying a parcel, whereby individuals face a big challenge to their own knowledge of the construction conditions on the site and construction itself. Residents state that "necessary information about the microclimate, way of life, convenience for the construction, customs, tradition and so on," were obtained through contacts with the locals. During the process, which takes anywhere from several months to several years, informal self-builders communicate with neighbours, who loan them tools, materials and electricity, offer refreshments, help with manual work, meet the workers, exchange experiences and so on. Skotte (2004) explains this as a strategy in which housing, as a node, activates the constitution of the society. In building a house, people build themselves in relation to the neighbourhood and so they express the spirit of place (Norberg-Schulz, 1979).

In contrast, the interest in the construction of the Ilsvika neighbourhood is expressed in the form of private investment and construction for the market. The main objective is profit, and so the process is conducted by a series of analyses looking for the most cost-effective solution. The project is led by rational business decisions according to laws and regulations (Internet 2), but also by taking care of only one's own interest. An interviewee who worked at a development company said that "because the price of planning and the land was very high and the market was not developed, the profitability of the project dictated its design, high density and relation to the old structures".

Meeting the neighbourhood's common public needs was conditioned just by minimal standards. Although the process was and still is open to citizens (Internet 3) they are not interested in participating and are rarely involved. The public interest was protected only partially by the residents of the old "fishing village", who formed a non-governmental organisation (NGO) and opposed the maximalist demands of the 


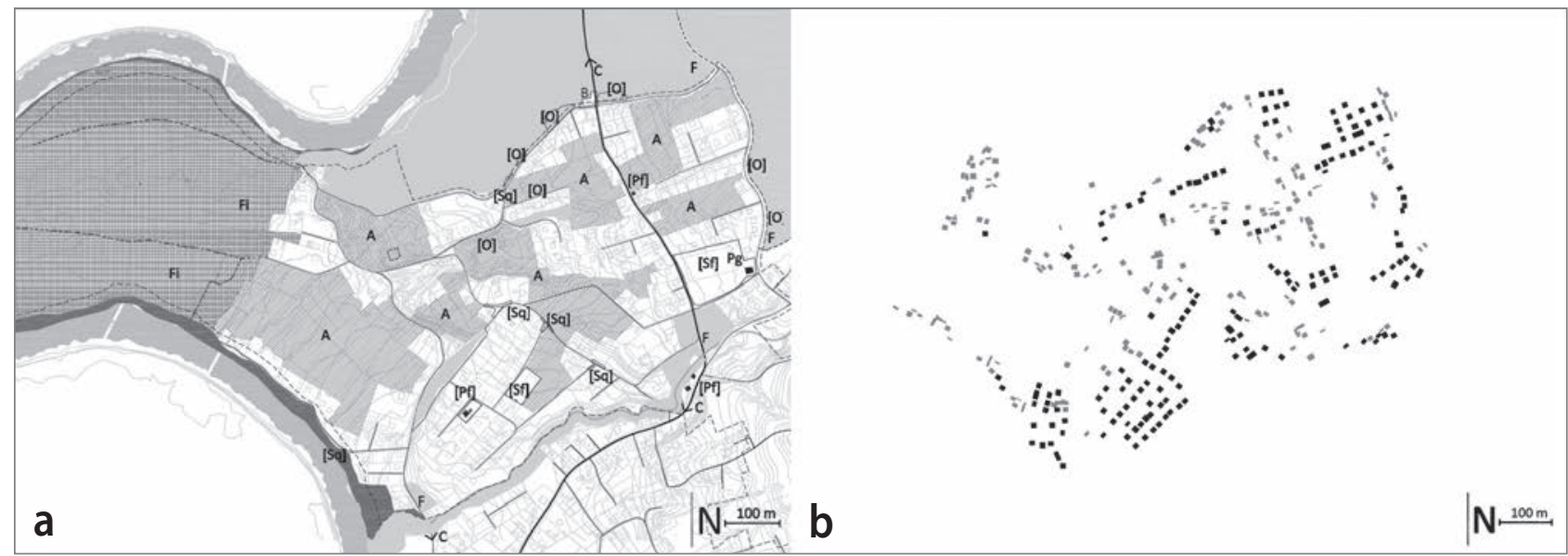

Figure 7: a) Open spaces in Mađir: F - forest, Fi - field, A - agricultural land, C - direction of city centre, $\mathrm{O}$ - occupied space that is used as public space, Pf - public facilities, Sf - sport facilities, Sq - improvised squares; b) old and new urban matrix in Mađir (illustration: Igor Kuvač).

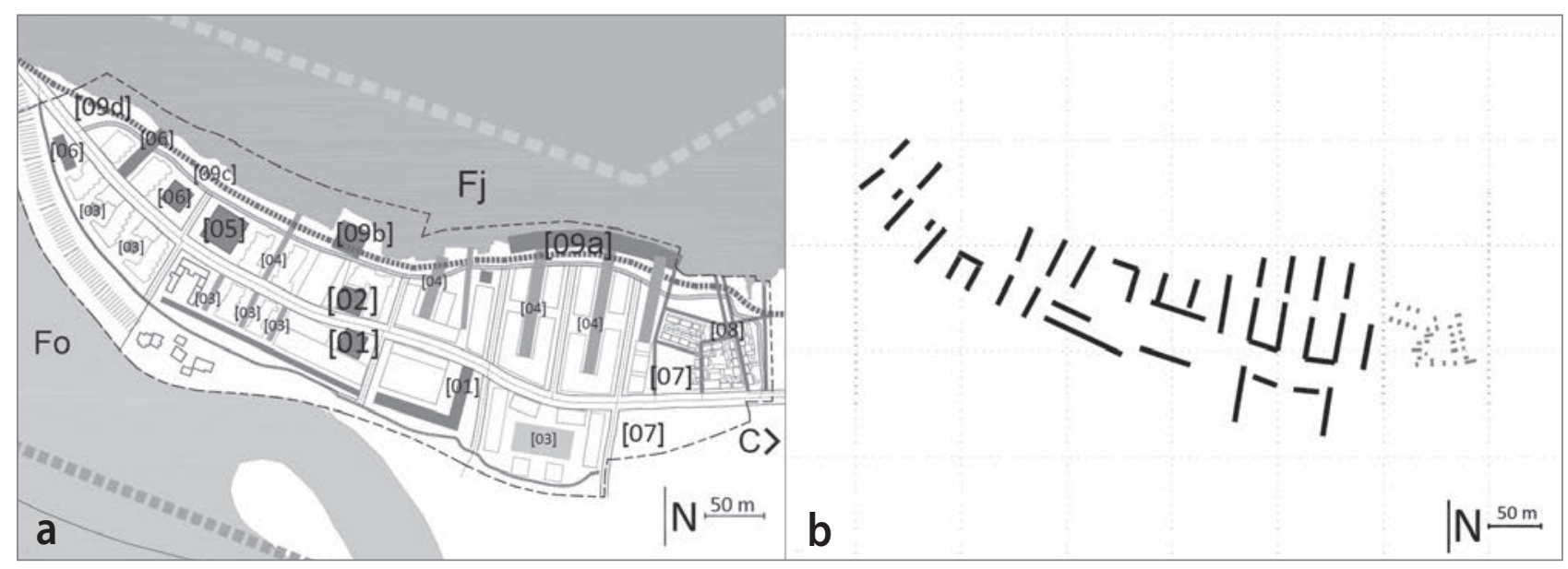

Figure 8: a) Open spaces in Ilsvika. Fo - forest, Fj - fjord, C - direction of city centre, 01-09 - types of public spaces; b) old and new urban matrix in Ilsvika (illustration: Igor Kuvač).

developers (Internet 4). As such, the small fishing village preserved its autonomy as a protected complex due to minimal compliance with existing legislative acts, but no more than that. In general, there was no common interest and it did not lead to integration of the old and new parts of neighbourhood, so the opportunity for better spatial and social results was missed. The village remained isolated and surrounded by a new high-density development, although it could serve as a good model for new construction, considering its urban qualities and social cohesion.

There is a great deal of trust in the competence of authorities, agencies and institutions in Norway, which are supposed to find the best solutions for the benefit of citizens and ensure that there are no failures. It is believed that the regulated state and its institutions manage resources in best possible way and that experts deal with all segments of social development including the plans, design and construction. Because spatial planning documentation is designed according to the highest standards, it is "understood that spatial results and the quality of life in those spaces should be satisfactory". However, Nataša Bratina Jurkovič (2014) states that "planners often neglect users' experience and values, and space consequently does not suit users' needs and requirements".

Unfortunately, the ultimate appearance of the neighbourhood and social interaction show that the results are not the best. An interviewee claims that "real democracy is not very present in the decision-making processes", regardless of the high level of human rights and freedoms Norway provides. It is observed that a top-down system shows a number of disadvantages. Although all the listed parameters have been applied, sociological analysis shows that people are not satisfied and that there is something missing (Tjora et al., 2012). The residents say that the neighbourhood is not suitable for personal needs, requirements or preferences because is formed according to general, unified and generic rules. "We didn't have any impact on the planned solutions. Because it was developed according to the model of most profitable solution, the individuals fit into an 
already completed project, buying their flats on a "key in the hand' basis without any opportunity to change it".

It is assumed that additional identity construction should happen after moving in and after coexisting with others, but this does not always happen. Although there is an opportunity for "coexistence" in public spaces, and although residents are not satisfied with the social interaction and integration with the neighbourhood, they still remain confined to "their own four walls". The third element of analysis, action in place, is considered below.

\subsection{Action in place}

Action in place is analysed through the patterns of living and using open public spaces, and is considered as the third component of construction of identities (Jurkovič Bratina, 2014). The notable difference between the two ways of identity construction is in the relationship between people and space and the social interactions achieved.

Urban activity in open public spaces almost does not exist in Madir, because there are no public spaces constructed. The "public space" is reduced only to the street and extensions next to it in the zone between the street and private, fenced front gardens. Residents became "aware of this when they had resolved the main problems, but by then it was too late". On the other hand, due to its location on the border between urban and rural areas, the neighbourhood is close to nearby hills, forests, fields, river banks and agricultural land, which are considered a type of provisional public space. Even though some of these are private properties, residents use them as public ones in an informal way. This use begins spontaneously from a desire to explore, meet and "conquer" the space, but also from the need for interaction. Because they are not marked or equipped, interaction is reduced only to casual meetings, and conditionally to a later conversation (Figure 7a).

As they self-constructed their houses and neighbourhood, residents felt that they also had the right to occupy some other spaces, so they feel free to usurp space that does not have a public function. In a way, the process of "conquering" and subsequent creation of a kind of "public" space was a natural consequence of constructing a neighbourhood, but neither one was complete. They had numerous limitations, especially considering the temporariness and questionable legality of these actions. Finally, in many cases the actual owners of these private properties have arrived to give them their own final purpose. Thus, the residents remain without important parts of the space that marks the only common public life of the neighbourhood, and they are forced to find alternatives or they just give up, tired of searching.
The relationship towards neighbourhood is radically different in Ilsvika. Apart from many typical public spaces, there are also empty open public spaces for different activities and open spaces between housing buildings: yards, paths, piers on the beach and so on. (Figure 8a). There is also a system of open spaces in natural surroundings that has a great effect on the quality and way of life in the neighbourhood (Bratina Jurkovič, 2014). Despite of this wide-ranging typology, open spaces are not used enough, which leads to a lack of social activity and the sense of a void. None of the interviewees said that they use open public spaces in their neighbourhoods and they themselves have noticed that some spaces, like the central square near the main street, "are constantly empty, grey and dusty". Even though the neighbourhood has the predisposition of a pleasant place to live, interviewees state that "something went wrong".

Considering the excellent transport connections and the opportunities to spend their free time wherever they want, residents mostly do not hang out in the neighbourhood. However, when they are there, they usually spend their free time in their own private flats within multi-family housing. Thus, the important parts of the living space are semi-private spaces (flat terraces) that emerge from connection with private ones instead of public ones. They are formed around regular zones of housing units that are designed with large glass surfaces and oriented towards semi-public green spaces between buildings; that is, towards their neighbours (Figure 6b). In this framework there is no visible action in place, and no urban activities that would produce a sense of belonging with neighbourhood life can be expected.

\section{Conclusion}

The findings result from a qualitative analysis using a triangle model with three recognised elements of neighbourhoods' identity construction. As mentioned above, these are: 1) spatial context, 2) participation in neighbourhood planning and construction processes and 3) action in place. They have been qualitatively analysed through: a) an analysis of urban planning documentation, b) field observations and c) a qualitative analysis of semi-structured interviews. Accordingly, all similarities and differences found are connected with these three common points, bearing in mind that different elements have different impacts on the identity issues. Conclusions are drawn with regard to physical structure (urban patterns of construction), public participation (unplanned cooperation) and place attachment (relativisation of identity). 


\subsection{Urban patterns of construction}

Construction of spatial identity in both cases mostly takes place according to the urban patterns of the place identity already present in its particular context. The existing urban pattern is simply repeated (i.e., moved from place to place through a certain type of transformation). Whereas in Madir there is literal repetition, in Ilsvika there is creative transposition.

The new urban pattern in Madir follows the existing rural structure of the neighbourhood by repeating the local context and fitting it into the existing urban frame. The vernacular self-builder intuitively respects traditional construction qualities, and so this approach has positive effects on spatial identity. However, it is not aware of the scale of transformation, leading to a clumsy urban structure and degradation of the environment and the traditional model used. Urban evolution is denied, and "urbanisation" means "ruralisation" of the neighbourhood and the city. The positive side is that both old and new achieve a certain coherence (Figures 2, 5, 7) and have some positive effects on the continuity of urban identity.

In contrast, the new urban pattern in Ilsvika creatively transposes the existing urban model, keeping some of the existing rural elements but achieving urbanisation. However, the existing model is transposed beyond recognition, so that the new part is much bigger than the old one, which completely surrounds it and dominates it. Although it is somewhat protected, the old structure remains isolated without real integration and is more like a monument in relation to the new one (Figures 3, 6, 8). In this way, the new physical structure decreases the significance of the existing one as a symbol of identity, which is lost due to the neoliberal capitalist model of construction and development.

In general, the lack of diversity is felt in both new neighbourhood sections. The new urban structure without additional values is predominant, and so both the new constructions take on a monotonous character. This shows that none of formal or informal approaches to new constructions improved the quality of the place. In both cases the old part of neighbourhood maintains its characteristic spatial identity, which is at the same time minimised. In order to get the new part of the neighbourhood to follow existing qualities of the place, old and new units should have better connections and achieve a kind of integration by respecting the scales of transformation. It turns out that the construction of spatial identity is much more complex than just apparent protection (Ilsvika) or repetition of existing urban patterns (Madir), and that a creative approach that combines the two methods applied might be satisfactory. Our analysis suggests that the real integration of existing values with the new parts of the neighbourhood can contribute to a stronger place attachment and have a special sensitivity to protection and improvement of urban identity.

\section{2 (Un)planned cooperation}

Lappegard Hauge (2009) states that people can be divided into three groups when it comes to awareness of their dwellings as communicating identity: 1) people who do not think much about it, 2) people who think a little about the issue and 3) people who discuss the issue spontaneously and are concerned about the matter. Unfortunately, none of these groups are inspired to direct action, and the analysis shows an undeveloped relationship towards the ongoing processes in the neighbourhoods, which does not contribute to place identity. Guided by the principle of "I don't care about anything unless it's happening in my backyard," the residents of both cities do not participate in urban planning processes. In Madir they "took matters into their own hands" and acted outside of the planning system, which at the same time did not work. Although they self-constructed their homes, they did not construct public spaces, which they now lack. Taking the initiative to construct these afterwards and to maintain the community energy from the period private house construction has not shown satisfactory results. On the other hand, although the residents had opportunities to act, this process was left to the responsible institutions in Ilsvika, with the expectation of good results. Because they did not participate in the development process, the residents of Ilsvika did not construct feelings toward the place and they do not feel the need to create a neighbourhood social life.

The (un)planned system of construction and other factors are obvious in terms of the (in)efficiency of a neighbourhood's identity construction. Twenty years after construction began, everything is missing in Madir apart from built but unfinished houses. The number of unresolved spatial problems is causing growing discontent and social interaction is declining because self-constructing their houses was not enough to offer a satisfying quality of life. In contrast, Ilsvika is completely finished and life takes place normally, but without place attachment. We conclude that in the case of Madir the construction of the neighbourhood was exclusively about the small "personal" interest of the vernacular builder, whose main goal was to satisfy basic needs, whereas in the case of Ilsvika it was about the "private" interest of a big investor, whose main objective was to generate profit. The disadvantages of these approaches show that creating a living space should not be a subject of interest to only of "one small vernacular builder" or just "one large investor". As a common right of all citizens, urban space must be a subject of broader social debate and a large number of participants led by experts, residents and responsible institutions in all phases of development. The interest of both 
residents and the public towards urban space can be directed through creative participation in urban spatial planning and the design of new activities, as Bratina Jurkovič (2014) suggests.

\subsection{Relativisation of identity}

According to the triads, spatial identity is (not) being constructed in the interaction of three elements that make place. As the analysis showed, general social interaction during construction was not enough, and therefore the construction of identity was not complete. A "free man" in Madir lives without trusting institutions and without awareness of the need to build confidence in them. Residents think that their self-constructed houses express their newly self-constructed identity but unfortunately this is not complete, and it does not reflect at the level of the neighbourhood as a whole. On the other hand, personal freedoms in Isvivika are way ahead of the community and have already surpassed it. Residents show realistic attitudes towards identity, but they do not consider it an important subject. There is no feeling of absence because identity is not in question and because it is considered as an already present component. There is not enough awareness in either case for the construction of identities as an important part of the space. The forms of urban space achieved do not lead to an adequate relationship towards the community nor do they stimulate actions in place. Mutual influences of social and spatial identity are left aside so the cohesion between them is not really achieved. Although spatial identity should be one of the priorities in new constructions, it is relativised and suppressed compared to other aspects of the urban environment. It always exists as in a certain form but its influence and essential meaning are unclear. Identity construction that meets the standards of high-quality life in the neighbourhood should include cooperation in every phase of planning, construction and the use of space. Only through the real integration of various needs for urban activities it would be possible to construct a valuable spatial identity. We must consider the historical and essential relationship between people and place: new urbanisations should have more appropriate attitudes toward the meaning of spatial identity, which is undoubtedly affected by new construction whether it is denied, changed or improved.

\section{Igor Kuvač}

University of Granada, Department of Urban and Spatial Planning

Granada, Spain

E-mail: igropop@gmail.com

\section{Markus Schwai}

Norwegian University of Science and Technology, Faculty of Architecture and Fine Arts, Department of Urban Design and Planning, Trondheim, Norway

E-mail: markus.schwai@ntnu.no

\section{Acknowledgments}

We would like to thank the Department of urban design and planning (NTNU, Trondheim, Norway), Join EU-SEE scholarship scheme and Professor José Luis Gómez Ordóñez (Department of urban design and planning, University of Granada, Spain).

\section{Notes}

${ }^{[1]}$ Sekulić was writing at the time when several South Slavic peoples lived in the unified country of the Kingdom of Yugoslavia. Due to their cultural connection, no difference has been made between the various peoples of the former Yugoslavia in this paper.

[2] "Nation" refers to the unique mentality of the specific region, and not only one nation.

${ }^{[3]}$ Approx. 100,000 people were killed and 300,000 wounded 450,000 house units destroyed or damaged and 2 million people displaced from their homes or became refugees (UNHCR, 2004).

[4] Physical Planning and Building Act (Serb. Zakon o prostornom uređenju i građenju, 2013); Decision legalising illegally started or constructed buildings or parts of buildings in Banjaluka (Serb. Odluka o legalizaciji bespravno početih ili izgrađenih objekata ili dijelova objekata na teritoriji grada Banjaluka, 2011).

\section{References}

Aranya, R. \& Ulset, V. (2015) Incipient informality in Delhi's "formalized" suburban space. In: Chakravarty, S. \& Negi, R. (eds.) Space, planning and everyday contestations in Delhi, pp. 91-110. New Delhi, Springer.

Bratina Jurkovič, N. (2014) Perception, experience and the use of public urban spaces by residents of urban neighbourhoods. Urbani izziv, 25(1), pp. 107-125. DOI: 10.5379/urbani-izziv-en-2014-25-01-003

Castells, M. (2009) The power of identity: The information age: Economy, society, and culture. New York, Wiley-Blackwell.

Cvijić, J. (1966) Balkansko poluostrvo i južnoslovenske zemlje. Belgrade, ZIU SR Srbije.

Dovey, K. (2010) Becoming places. London, Routledge.

Gillis, J. R. (1994) Memory and identity: The history of relationship. In: Gillis, J. R. (ed.) Commemorations: The politics of national identity, pp. 3-24. Princeton, Princeton University Press.

Hall, P. (1996) Cities of tomorrow. Oxford, Blackwell Publishers.

Hall, S. (2000) "Who needs 〈identity)?" In: du Gay, P., Evans, J. \& Redman, P. (eds.) Identity: a reader, pp. 15-30. London, Sage Publications.

Hamsun, K. (1927) Pan. New York, Alfred A. Knopf.

Hoxha, V., Dimitrovska Andrews, K. \& Temeljotov Salaj, A. (2014) Cultural factors affecting urban planners' intentions to regulate public space in Prishtina, Kosovo. Urbani izziv, 25(2), pp. 76-89. DOI: 10.5379/urbani-izziv-en-2014-25-02-001

Ibelings, H. (2010) Restart: Arhitektura Bosnia-Herzegovina 1995-2010. Sarajevo, BuyBook.

Institute of statistics of the Republic of Srpska (2014) Preliminary results of the Census of population, households and dwellings in BH 2013, for cities and municipalities of Republika Srpska. Second, corrected release. Banjaluka. 
Internet 1: http://data.un.org/Data.aspx?d=POP\&f=tableCode\%3A240 (accessed 16 Mar. 2015).

Internet 2: https://geoinnsyn.nois.no/trondheim/?project=trondheim (accessed 2 Mar. 2015).

Internet 3: https://lovdata.no/dokument/NL/lov/2008-06-27-71 (accessed 25 Mar. 2015).

Internet 4: http://www.gulesider.no/f/ilsvik\%C3\%B8ra-velforening:85353683 (accessed 16 Mar. 2015).

Karan, I. (2014) Trebinje on the border between East and West. Heritage and memory of Trebinje Bosnian-Herzegovinian town, Bitacora, 24(2) pp. 31-41.

Kvale, S. \& Brinkmann, S. (2009) Interviews, Learning the Craft of Qualitative Research Interviewing. London, Sage Publications.

Lappegard Hauge, Å. (2009) Housing and Identity. The meaning of housing in communicating identity and its influence on self-perception. Doctoral thesis. Trondheim, NTNU.

Lefebvre, H. (2013) La produccion del espacio. Madrid, Capitan Swing Libros S. L.

Lynch, K. (1974) Slika jednog grada. Belgrade, Građevinska knjiga.

Mason, J. (2006) Mixing methods in a qualitatively driven way. Qualitative research, 6(1), pp. 9-25. DOI: 10.1177/1468794106058866

Meili, M., Diener, R., Topalović, M. \& Muller Inderbitzin, C. (2012) Belgrade. Formal / informal: A research on urban transformation. Basel, Verlag Scheidegger \& Spiess.

Ministry of Finance and Treasury of Bosnia and Herzegovina \& Office of the UN Resident Coordinator in Bosnia and Herzegovina (2013) Progress towards the Realisation of Millennium Development Goals in Bosnia and Herzegovina. Report. Sarajevo.

Murphy, M. A. (2011) Boundaries to socially and environmentally equitable communal spaces - finding common ground for a sustainable urban existence in multicultural Oslo. Master's thesis. Trondheim, NTNU.

Neil, W. J. V. (2004) Urban planning and cultural identity. London, Routledge. DOI: $10.4324 / 9780203402245$

Norberg-Schulz, C. (1979) Genius loci: towards a phenomenology of architecture. New York, Rizzoli.

Odluka o legalizaciji bespravno početih ili izgrađenih objekata ili dijelova objekata na teritoriji grada Banjaluka. Službeni glasnik grada Banjaluka, no. 11/11. Banjaluka.

OECD (2014) OECD Economic Surveys. Norway. March 2014. Overview. Available at: http://www.oecd.org/eco/surveys/Norway-Overview-2014. pdf (accessed 26 Mar. 2015).

Relph, E. (1976) Place and placelessness. London, Pion Limited.

Seamon, D. (2012) Place, place identity, and phenomenology: A triadic interpretation based on J.G. Bennett's systematics. In: Casakin, H. \& Bernardo, F. (eds.) The role of place identity in the perception, understanding, and design of built environments, pp. 3-21. Sharjah, Bentham Science Publishers. DOI: 10.2174/97816080541381120101

Sejranović, B. (2010) Ljepši kraj. Sarajevo, Buybook.

Sekulić, I. $(1914,2001)$ Pisma iz Norveške i drugi putopisi. Novi Sad, Stylos art.

Sekulić, I. (1932) Beleška o malom narodu. Srpski književni glasnik, 35(6), pp. 422-426.

Simonović, D. (2010) Pejzažni gradovi, poređenje razvoja urbanog identiteta Banjaluke i Graca. Banjaluka, Arhitektonsko-građevinski fakultet.
Simonović, D. (2013) Rehabilitation of urban identity of cities in the Banjaluka region through urban form regulation. SPATIUM International Review, 30(12), pp. 28-32. DOI: 10.2298/SPAT1330028S

Skotte, H. (2004) Tents in Concrete. What internationally funded housing does to support recovery in areas affected by war. The case of Bosnia and Herzegovina. Doctoral thesis. Trondheim, NTNU.

Skotte, H., Čengić, N. \& Svendsen, S. E. (2015) Now it's mine. How and why Sarajevo's new post-war residents have self-settled in and around the city. Typescript.

Soja, E. W. (1998) Thirdspace: journeys to Los Angeles and other real-andimagined places, Malden, Blackwell.

Solà-Morales i Rubió, M. (2003) Las formas del crecimiento urbano. Barcelona, Universidad Politécnica de Cataluña.

Tjora, A., Henriksen, I. A., Fjærli, T. \& Grønning, I. (2012) Sammen i byen: en sosiologisk analyse av urbane naboskap, nærmiljoe og boligens betydning. Trondheim, Tapir Akademisk Forlag.

Transparency International Bosnia and Herzegovina (2014) Percepcija javne uprave, Bosna i Hercegovina 2014. Banjaluka. Available at: http:// ti-Bosnia-Herzegovina.org/wp-content/uploads/2015/03/TI-BOSNIAHERZEGOVINA-Percepcija-Javne-Uprave-Bosnia-Herzegovina-2014.pdf (accessed 24 Apr. 2015).

UNHCR (2004) Returns to Bosnia and Herzegovina reach 1 million. Available at: http://www.unhcr.org (accessed 9 Sep. 2014).

Watson, G. B. \& Bentley, I. (2007) Identity by design. Oxford, Elsevier Ltd.

Zakon o prostornom uređenju i građenju Republike Srpske. Službeni Glasnik Republike Srpske 40/13. Banjaluka. 